\title{
PENERAPAN MODEL PEMBELAJARAN KOOPERATIF TIPE TEAM GAMES TOURNAMENT (TGT) DALAM UPAYA PENINGKATAN HASIL BELAJAR FIQIH SISWA DI KELAS II MADRASAH IBTIDAIYAH NEGERI 6 LANGKAT BOHOROK
}

\author{
Dahliana \\ Surel : dahlianaspd86@gmail.com
}

\begin{abstract}
Student learning outcomes by establishing a Team Games Tournament (TGT) Type Cooperative Learning Model have improved quite well. Before the class action (PTK) was carried out for the initial test, the average score of the Islamic Civilization History class II class II Madrasah Ibtidaiyah Negeri 6 Langkat Bohorok, which amounted to 31 students, was 70 (moderate category) and the standard deviation was 8,116. After the class action was carried out in cycle I for the first final test, the average score of Islamic Civilization History subjects increased to 74 (moderate category) and the standard deviation was 6.825. Followed by class action in cycle II for the second final test, the average value of Islamic Civilization History subjects increased to 80 (high category) and the standard deviation was 4.479 with a minimum completeness criteria value (KKM) of 65. Next, the correlation between the initial test and cycle I was 0.766 . (quite significant category) with a t test value of 6.53, and the correlation between cycle I and cycle II was 0.95 (very significant category) with a t test value of 16.578 . And before the action was carried out the average attendance rate of students was $80 \%$, after the action was carried out in the first cycle it became $89 \%$, in the second cycle it was $100 \%$. In general, students learn to be more independent.
\end{abstract}

Keywords: Classroom action research (PTK), Cooperative Learning Model Type Team Games Tournament (TGT), Student Islamic Civilization History Learning Outcomes

\begin{abstract}
ABSTRAK
Hasil belajar siswa dengan menetapkan Model Pembelajaran Kooperatif Tipe Team Games Tournament (TGT) telah terjadi peningkatan cukup baik. Sebelum dilaksanakan tindakan kelas (PTK) untuk test awal, nilai rata-rata mata pelajaran Fiqih siswa kelas II Madrasah Ibtidaiyah Negeri 6 Langkat Bohorok yang berjumlah 31 orang siswa, sebesar 70 (katagori sedang) dan simpangan baku 8,116. Setelah dilakukannya tindakan kelas pada siklus I untuk test akhir pertama nilai rata-rata mata pelajaran Fiqih meningkat menjadi 74 (katagori sedang) dan simpangan baku 6,825. Dilanjutkan tindakan kelas pada siklus II untuk test akhir kedua nilai rata-rata mata pelajaran Fiqih meningkat menjadi 80 (katagori tinggi) dan simpangan baku 4,479 dengan nilai kriteria ketuntsan minimum (KKM) sebesar 65. Berikutnya, korelasi antara test awal terhadap siklus I sebesar 0,766 (katagori cukup signifikan) dengan nilai uji t sebesar 6,53, dan korelasi antara siklus I terhadap siklus II sebesar 0,95 (katagori sangat signifikan) dengan nilai uji t sebesar 16,578. Dan sebelum dilaksanakan tindakan tingkat kehadiran rata-rata siswa $80 \%$, setelah dilaksanakan tindakan pada siklus I menjadi 89\%, pada siklus II menjadi 100\%. Secara umum siswa belajar menjadi lebih mandiri.
\end{abstract}

Kata Kunci: Penelitian Tindakan Kelas (PTK), Model Pembelajaran Kooperatif Tipe Team Games Tournament (TGT), Hasil Belajar Fiqih Siswa 


\section{PENDAHULUAN}

Saat ini kita dihadapkan kepada tuntutan dunia pendidikan yang lebih baik dan berkualitas. Untuk memenuhi kebutuhan pendidikan yang berkualitas tersebut diperlukan tenaga kependidikan atau guru yang berkualitas pula. Banyak faktor yang mendukung untuk menciptakan guru yang berkualitas, diantaranya adalah sistem dan komponen pendidikan yang mengacu kepada standarisasi pendidikan yang berkualitas. Faktor yang paling utama pendidikan yang berkualitas berasal dari guru, kemauan siswa, dan komitmen orangtua siswa (wali murid). Perlu diketahui bahwa keberada an guru di dalam kelas haruslah menjadi perhatian yang serius dalam pelaksanaan pendidikan sekarang ini. Guru hendaklah dapat mengubah paradigma mengajar sebagai sebuah pelaksanaan tugas kerja menjadi sebuah proses perubahan yang dapat meningkatkan kualitas pengetahuan siswa dari tidak paham menjadi paham, dari tidak biasa menjadi terbiasa, dan dari tidak berkompetensi menjadi berkompetensi. Sehingga siswa memperoleh hasil belajar yang bagus, aktif dan kreatif, serta berdedikasi yang tinggi. Mata pelajaran Fiqih merupakan salah satu mata pelajaran yang harus dipelajari di sekolah tingkat MI/MTs /MA, terkhusus di kelas II Madrasah Ibtidaiyah Negeri 6 Langkat Bohorok dengan jumlah siswa sebanyak 31 orang dan beralamat di jalan Ampera pekan Bohorok kabupaten Langkat Sumatera Utara, yang mempelajari tentang hukum-hukum Islam berpedomankan Al Qur'an dan Hadist, baik bersifat wajib, sunnah, maupun haram, yang harus dilaksanakan dalam kehidupan sehari-hari bagi ummat Islam. Agar belajar Fiqih menyenangkan siswa dan dapat diperaktekkan langsung dalam kehidupan sehari-hari, maka guru Fiqih berusaha mencari model pembelajaran yang tepat bagi siswa. Untuk itu perlu kiranya dikembangkan model pembelajaran yang dapat meningkatkan aktif dan kreatif siswa, bekerjasama secara demokratis, saling tolong menolong baik untuk dirinya sendiri maupun untuk orang lain, yang pada akhirnya siswa memperoleh hasil belajar yang bagus. Model pembelajaran yang tepat adalah Model Pembelajaran Kooperatif Tipe Team Games Tournament (TGT). Model Pembelajaran Kooperatif Tipe Team Games Tournament (TGT) adalah suatu tipe pembelajar-an Kooperatif untuk mendorong siswa saling membantu dan memotivasi serta menguasai keterampilan yang dibentuk oleh guru. Dan dalam suatu kelas tertentu siswa dibagi menjadi kelompok dengan anggota beberapa orang, setiap kelompok haruslah hiterogen, terdiri dari laki-laki dan perempuan, memiliki kemampuan yang tinggi, sedang dan rendah, sementara guru menyiapkan permainan yang disiapkan dalam bentuk kartu soal, atau lembar kerja siswa. Pada akhirnya kegiatan pembelajaran yang 
dilaksanakan akan ditentukan pemenangnya.

Model Pembelajaran Kooperatif Tipe Team Games Tournament (TGT) menekankan pada kesadaran siswa untuk belajar berfikir, memecahkan masalah sebagai aplikasi dari pengetahuan dan ketrampilan, saling berbagi pengetahuan dan konsep, serta saling tolong menolong satu sama yang lainnya dalam menghadapi per masalahan. Agar proses pembelajar annya tidak membosankan, maka Model Pembelajaran ini dibuat seperti bermain games, dimana guru menyiapkan permainan dalam bentuk kartu yang berisikan soal, siswa yang dapat menjawab dengan benar, siswa itulah pemenangnya dan akan diberi hadiah.

Dalam penggunaan Model Pembelajaran ini, guru berupaya agar siswa mendapatkan hasil belajar yang lebih baik lagi. Upaya diartikan sebagai usaha kegiatan yang mengarahkan tenaga, pikiran untuk mencapai suatu tujuan. Upaya juga berarti usaha, akal, ikhtiar untuk mencapai suatu maksud, memecah kan persoalan mencari jalan keluar. Pada dasarnya upaya dapat diartikan sebagai suatu usaha berbentuk kegiatan yang membutuhkan tenaga, pikiran yang sehat dan ikhtiar yang kuat guna mencapai suatu maksud atau tujuan yang ingin dicapai, atau usaha sadar mencari jalan keluar dalam memecahkan suatu persoalan. Dan hasil belajar adalah kemampuankemampuan yang dimiliki peserta didik setelah dia menerima pengalam an belajarnya. Hasil belajar diguna kan guru untuk dijadikan ukuran kriteria dalam mencapai suatu tujuan pendidikan. HaI ini dapat tercapai apabila peserta didik telah memaha mi belajar dengan diiringi oleh perubahan tingkah laku yang lebih baik lagi. Hasil belajar mempunyai peran penting, dalam proses pembelajaran penilaian terhadap hasil belajar dapat memberikan informasi kepada guru tentang kemajuan peserta didik dalam upaya mencapai tujuan-tujuan belajarnya melalui kegiatan belajar.

Penelitian ini memiliki tujuan sebagai berikut : untuk mengetahui penerapan model pembelajaran Kooperatif Tipe Team Games Tournament (TGT) dapat meningkat kan hasil belajar Fiqih siswa di kelas II Madrasah Ibtidaiyah Negeri 6 Langkat Bohorok, dan untuk menge tahui penerapan model pembelajaran Kooperatif Tipe Team Games Tournament (TGT) dapat meningkatkan aktifitas belajar Fiqih siswa di kelas II Madrasah Ibtidaiyah Negeri 6 Langkat Bohorok.

\section{METODE PENELITIAN}

Penelitian tindakan kelas (PTK) ini dilaksanakan dalam dua siklus selama tiga bulan di kelas II Madrasah Ibtidaiyah Negeri 6 Langkat Bohorok semester ganjil Tahun Pelajaran 2019/2020 yang beralamat di jalan Ampera pekan Bohorok kabupaten Langkat Suma tera Utara, dengan jumlah siswa sebanyak 31 orang. 
Pada model Pembelajaran Kooperatif Tipe Team Games Tournament (TGT) ini siswa dibagi menjadi beberapa kelompok dengan anggota sebanyak 5 sampai 8 orang. Dimana tiap kelompoknya bersifat hiterogen, yang terdiri dari pria dan wanita yang memiliki kemampuan tinggi, sedang, dan rendah. Anggota team diberi nomor, dan masingmasing yang mendapat nomor akan diberi soal atau masalah yang harus dipikirkan secara bersama oleh anggota kelompoknya. Sementara guru mempersiapkan perangkat pembelajaran berupa ; RPP, materi ajar, buku paket, soal-soal, alat-alat pembelajaran dan penilaian, dan lainnya. Beberapa unsur dalam model Pembelajaran Kooperatif Tipe Team Games Tournament (TGT) ini sebagai berikut ; Siswa dalam kelom poknya haruslah beranggapan bahwa mereka sehidup dan sepenanggungan bersama, Siswa bertanggung jawab atas segala sesuatu tindakan di dalam kelompok nya, Siswa haruslah me lihat bahwa semua anggota di dalam kelompok nya memiliki tujuan yang sama, Siswa akan dikenakan evaluasi atau diberikan hadiah penghargaan yang juga akan dikenakan untuk semua anggota kelompoknya, Siswa berbagi kepemimpinan dan mereka membu tuhkan keterampilan untuk belajar bersama selama proses belajarnya, Siswa bekerja dalam kelompok secara kooperatif untuk menuntaskan materi belajarnya, Kelompok di bentuk dari siswa yang memiliki kemampuan tinggi, sedang, dan rendah, Penghargaan diberikan pada tiap anggota kelompok yang mempunyai prestasi yang baik.

Prosedur kerja, dalam penelitian ini, dilakukan terdiri dari dua siklus dan 10 pertemuan (20 jam). Kegiatan awal dua kali pertemuan, memberikan test awal atau pre test. Setelah kegiatan pada siklus I berlangsung selama empat kali pertemuan, selanjutnya diikuti oleh kegiatan pada siklus II selama tiga kali pertemuan, dan pengelolaan nilai selama satu kali pertemuan, dimana tindakan yang dilakukan pada siklus II merupakan refleksi (cerminan) dari kegiatan pada siklus I, dengan rincian sebagai berikut.

Pertama, pada pertemuan kedua, guru menjelaskan tentang Model kooperatif tipe Team Games Tournament (TGT) terhadap siswa, serta kiat-kiat yang digunakan siswa dalam menerapkan model pembelajar an tersebut. Pada siklus I pelaksanaan tindakan kelas yang dilakukan meliputi : mengidentifikasi keadaan siswa berupa minat dan kesiapannya dalam pembelajaran dengan terlebih dahulu melakukan test awal sebelum kegiatan dilaksanakan (pertemuan pertama), membahas materi pelajaran dengan penerapan model Pembelajar an Kooperatif Tipe Team Games Tournament (TGT), setelah melaksanakan aktifitas pembelajaran kepada siswa dilakukan test akhir pertama (siklus I pertemuan keempat) untuk mengetahui tingkat prestasi yang dimiliki setelah dilakukan tindakan kelas dengan model Pembelajaran Kooperatif Tipe Team Games Tournament (TGT). 
Pengamatan (Observasi), selama berlangsung pembelajaran di dalam kelas dengan penerapan model Pembelajaran Kooperatif Tipe Team Games Tournament (TGT), guru yang lain melakukan pengamatan hal-hal yang terjadi, apa saja kegiatan yang dilakukan siswa, apakah sudah sesuai dengan yang direncanakan sebelumnya, disamping itu peneliti sebagai guru pembimbing bertindak juga sebagai pengamat. Refleksi, refleksi dari penelitian tindakan kelas (PTK) pada siklus I ini dimaksudkan untuk meningkatkan kemampuan siswa dalam melaku kan kerjasama kelompok dalam memecahkan masalah yang dihadapi dalam mata pelajaran Fiqih, dari data-data yang diperoleh sebagai hasil observasi dikumpulkan dan dianalisa, sehingga dapat disimpulkan langkah-langkah yang akan diambil dalam siklus berikutnya. Pada pertemuan kelima barulah siswa mulai terbiasa mengikuti model Pembelajaran Kooperatif tipe Team Games Tournament (TGT), Disini guru memberikan beberapa strategi dan teknik, serta motivasi kepada para siswa agar lebih giat dan teliti.

Kedua, pada siklus II pelaksanaan tindakan kelas yang dilakukan meliputi : mengidentifikasi kembali keadaan siswa berupa minat dan kesiapannya dalam pembelajaran dengan terlebih dahulu melakukan test berikutnya, membahas materi pelajaran dengan penerapan model Pembelajaran Kooperatif Tipe Team Games Tournament (TGT), Memasuki pertemuan ke-tujuh barulah pembelajaran menjadi terarah, siswa sudah mampu memecahkan sendiri masalahmasalah yang ada, bahkan siswa dapat membuat contoh-contoh soal sendiri kemudian memecahkannya. Pada kesempatan ini para siswa sudah mempunyai kepercayaan diri, ditandai semangkin banyaknya siswa yang tampil untuk menyelesaikan soal-soal yang diberikan. Setelah melaksanakan aktifitas pembelajaran kepada siswa dilakukan test akhir kedua (siklus II pertemuan kedelapan) untuk mengetahui tingkat prestasi yang dimiliki setelah dilakukan tindakan kelas dengan model Pembelajaran Kooperatif Tipe Team Games Tournament (TGT). Pengamatan (Observasi), selama berlangsung pembelajaran di dalam kelas dengan penerapan model Pembelajaran Kooperatif Tipe Team Games Tournament (TGT), guru yang lain melakukan pengamatan hal-hal yang terjadi, apa saja kegiatan yang dilakukan siswa, apakah sudah sesuai dengan yang direncanakan sebelumnya, disamping itu peneliti sebagai guru pembimbing bertindak juga sebagai pengamat pada siklus II. Refleksi, refleksi dari penelitian tindakan kelas (PTK) pada siklus II ini dimaksudkan untuk meningkatkan kemampuan siswa dalam melaku kan kerjasama kelompok dalam memecahkan masalah yang dihadapi dalam mata pelajaran Fiqih, dari data-data yang diperoleh sebagai hasil observasi dikumpulkan dan dianalisa, sehingga dapat disimpulkan langkah-langkah yang akan di- 
ambil dalam siklus berikutnya. Jika pada siklus II hasil belajar Fiqih dan keaktifan siswa sudah bagus, maka peneliti tidak perlu lagi melanjutkan penelitian ini.

Kegiatan Perencanaan berdasarkan pada refleksi dari siklus I, semen tara untuk langkah-langkah kegiatan tindakan dan pengamatan sama dengan siklus I dengan memperhatikan prioritas permasalahan yang disimpulkan pada siklus I dan dilanjutkan dengan kegiatan refleksi. Apabila hasil refleksi pada siklus II sudah menunjukkan adanya peningkatan kemampuan guru secara signifi kan, maka kegiatan penelitian dianggap berhasil, tetapi sebaliknya apabila belum menunjukan hasil yang di harapkan, maka kegiatan penelitian akan dilanjutkan dengan siklus berikutnya dengan langkah-langkah kegiatan yang sama dengan kegiatan pada siklus II ini. Metode pengumpulan data, pada penelitian ini berupa test awal pada awal kegiatan penelitian, dan test akhir dilaksanakan sebanyak dua kali yaitu test setelah selesai kegiatan pada siklus I, dan test akhir setelah selesai kegiatan pada siklus II. Melakukan observasi melalui lembar pengamatan pada setiap kegiatan dan beberapa tanggapan dari siswa terhadap kegiatan atau metode yang dilakukan dalam pembelajaran. Pem- berian test terhadap siswa dimaksud- kan untuk mengetahui hasil belajar siswa sebelum dan sesudah tindakan dilaksanakan, dan sejauh mana aktivitas dan kreatifitas siswa, serta kehadiran siswa dalam mengikuti pem- belajaran selama proses penelitian. Metode analisis data, dalam penelitian ini dilakukan teknik analisis data secara kuantitatif (perhitungan) dengan menggunakan statistik deskriftif, untuk mencari nilai rata-rata (mean), nilai sering muncul (modus), simpangan baku (standar deviasi), dan nilai korelasi (produc moment).

\section{HASIL PENELITIAN DAN PEMBAHASAN}

Sebelum dilaksanakan pembelajaran dengan penerapan model Pembelajaran Kooperatif Tipe Team Games Tournament (TGT), peneliti melakukan tes awal mata pelajaran Fiqih, yang materinya merupakan pelajaran yang sudah disampaikan oleh guru. Hal ini bertujuan untuk mengetahui sejauh mana kemampuan belajar siswa sebelum dilaksanakan tindakan. Disamping itu juga dilaksanakan wawancara terhadap sejumlah siswa yang diambil secara random (acak) tentang pelajaran Fiqih, cara mengajar guru serta masukan (saran) dari siswa tentang kesenangan mereka dalam belajar dengan menggunakan penerapan model Pembelajaran Kooperatif Tipe Team Games Tournament (TGT), karena pembelajarannya seperti permainan games.

Hasil penelitian yang dilaksanakan di kelas II Madrasah Ibtidaiyah Negeri 6 Langkat Bohorok yang jumlah siswanya sebanyak 31 orang, secara umum menunjukkan hasil yang sangat menggembirakan, 
dengan rincian sebagai berikut : nilai kriteria ketuntasan minimum (KKM) sebesar 65, test awal pelajaran Fiqih sebelum tindakan menghasilkan nilai rata-rata sebesar 70 dan 9 siswa (29\%) tidak tuntas, simpangan baku sebesar 8,116, ini artinya walaupun hasil belajar Fiqih siswa sudah di atas KKM namun masih ada 9 siswa yang harus remedial. Berikutnya, dilaksanakan pembelajaran dengan penerapan model Pembelajaran Kooperatif Tipe Team Games Tournament (TGT) pada silkus I dan test akhir pertama, menghasilkan nilai rata-rata sebesar 74 dan 6 siswa $(12,9 \%)$ tidak tuntas, simpangan baku sebesar 6,825, ini artinya hasil belajar Fiqih siswa sudah di atas nilai KKM, namun masih ada 4 siswa harus remedial. Selanjutnya, pada silkus II dan test akhir kedua, menghasilkan nilai rata-rata sebesar 83 dan 0 siswa (0\%) tidak tuntas, simpangan baku sebesar 4,479, ini artinya hasil belajar Fiqih siswa sudah di atas nilai KKM (100\% tuntas).

Untuk melihat adanya korelasi atau hubungan diperlukan rumus product moment dengan hasil perhitungan sebagai berikut : korelasi antara nilai hasil belajar Fiqih siswa pada test awal (sebelum tindakan) terhadap test akhir pertama (siklus I) sebesar 0,766 (kategori signifikan) dengan nilai uji t sebesar 6,53, dan korelasi antara nilai hasil belajar Fiqih siswa pada test akhir pertama (siklus I) terhadap test akhir kedua (tindakan siklus II) sebesar 0,95 (kategori sangat signifikan) dengan nilai uji $\mathrm{t}$ sebesar 16,578, lihat tabel :

Tabel 1. Rangkuman Perhitungan Rataan, Simpangan Baku dan Korelasi Hasil Belajar Fiqih Siswa Kelas II Madrasah Ibtidaiyah Negeri 6 Langkat Bohorok

\begin{tabular}{|c|c|c|c|c|c|c|c|c|c|c|}
\hline No & $\begin{array}{c}\mathrm{X} \\
\text { awal }\end{array}$ & X.X & $\begin{array}{c}\mathrm{Y} \\
\text { Siklus } \\
1 \\
\end{array}$ & Y.Y & X.Y & $\begin{array}{c}\mathrm{X} \\
\text { Siklus } \\
1 \\
\end{array}$ & X.X & $\begin{array}{c}\text { Y } \\
\text { Siklus } \\
2 \\
\end{array}$ & Y.Y & X.Y \\
\hline 1 & 78 & 6084 & 80 & 6400 & 6240 & 80 & 6400 & 85 & 7225 & 6800 \\
\hline 2 & 80 & 6400 & 82 & 6724 & 6560 & 82 & 6724 & 88 & 7744 & 7216 \\
\hline 3 & 79 & 6241 & 81 & 6561 & 6399 & 81 & 6561 & 86 & 7396 & 6966 \\
\hline 4 & 64 & 4096 & 77 & 5929 & 4928 & 77 & 5929 & 80 & 6400 & 6160 \\
\hline 5 & 74 & 5476 & 78 & 6084 & 5772 & 78 & 6084 & 83 & 6889 & 6474 \\
\hline 6 & 79 & 6241 & 81 & 6561 & 6399 & 81 & 6561 & 86 & 7396 & 6966 \\
\hline 7 & 80 & 6400 & 82 & 6724 & 6560 & 82 & 6724 & 87 & 7569 & 7134 \\
\hline 8 & 72 & 5184 & 78 & 6084 & 5616 & 78 & 6084 & 81 & 6561 & 6318 \\
\hline 9 & 64 & 4096 & 77 & 5929 & 4928 & 77 & 5929 & 80 & 6400 & 6160 \\
\hline 10 & 75 & 5625 & 80 & 6400 & 6000 & 80 & 6400 & 82 & 6724 & 6560 \\
\hline 11 & 60 & 3600 & 64 & 4096 & 3840 & 64 & 4096 & 78 & 6084 & 4992 \\
\hline 12 & 60 & 3600 & 64 & 4096 & 3840 & 64 & 4096 & 78 & 6084 & 4992 \\
\hline 13 & 78 & 6084 & 80 & 6400 & 6240 & 80 & 6400 & 85 & 7225 & 6800 \\
\hline 14 & 77 & 5929 & 80 & 6400 & 6160 & 80 & 6400 & 85 & 7225 & 6800 \\
\hline 15 & 78 & 6084 & 80 & 6400 & 6240 & 80 & 6400 & 85 & 7225 & 6800 \\
\hline 16 & 62 & 3844 & 64 & 4096 & 3968 & 64 & 4096 & 77 & 5929 & 4928 \\
\hline 17 & 63 & 3969 & 64 & 4096 & 4032 & 64 & 4096 & 78 & 6084 & 4992 \\
\hline 18 & 77 & 5929 & 80 & 6400 & 6160 & 80 & 6400 & 85 & 7225 & 6800 \\
\hline 19 & 77 & 5929 & 80 & 6400 & 6160 & 80 & 6400 & 85 & 7225 & 6800 \\
\hline 20 & 76 & 5776 & 80 & 6400 & 6080 & 80 & 6400 & 85 & 7225 & 6800 \\
\hline
\end{tabular}


Dahliana : Penerapan Model Pembelajaran ...

\begin{tabular}{c|c|c|c|c|c|c|c|c|c|c|c}
21 & 64 & 4096 & 77 & 5929 & 4928 & & 77 & 5929 & 80 & 6400 & 6160 \\
\hline 22 & 80 & 6400 & 85 & 7225 & 6800 & & 85 & 7225 & 89 & 7921 & 7565 \\
\hline 23 & 62 & 3844 & 64 & 4096 & 3968 & & 64 & 4096 & 75 & 5625 & 4800 \\
\hline 24 & 80 & 6400 & 82 & 6724 & 6560 & & 82 & 6724 & 88 & 7744 & 7216 \\
\hline 25 & 72 & 5184 & 77 & 5929 & 5544 & & 77 & 5929 & 80 & 6400 & 6160 \\
\hline 26 & 77 & 5929 & 80 & 6400 & 6160 & & 80 & 6400 & 86 & 7396 & 6880 \\
\hline 27 & 77 & 5929 & 80 & 6400 & 6160 & & 80 & 6400 & 85 & 7225 & 6800 \\
\hline 28 & 76 & 5776 & 78 & 6084 & 5928 & & 78 & 6084 & 84 & 7056 & 6552 \\
\hline 29 & 73 & 5329 & 78 & 6084 & 5694 & & 78 & 6084 & 80 & 6400 & 6240 \\
\hline 30 & 62 & 3844 & 64 & 4096 & 3968 & & 64 & 4096 & 78 & 6084 & 4992 \\
\hline 31 & 72 & 5184 & 77 & 5929 & 5544 & & 77 & 5929 & 81 & 6561 & 6237 \\
\hline & 2170 & 158418 & 2294 & 176676 & 167136 & & 2294 & 176676 & 2480 & 205422 & 190260 \\
\hline
\end{tabular}

Pembahasan

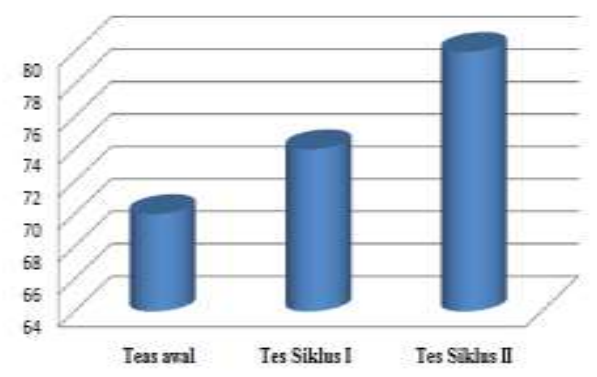

Gambar 1. Diagram Batang Nilai Rata-rata Hasil Belajar Fiqih Kelas II MIN 6 Langkat Bobrok

Diagram batang ini menunjukkan nilai rata-rata pelajaran Fiqih siswa semangkin meningkat, ini arti nya model pembelajaran tersebut sangat baik dalam meningkatkan hasil belajar siswa di kelas.

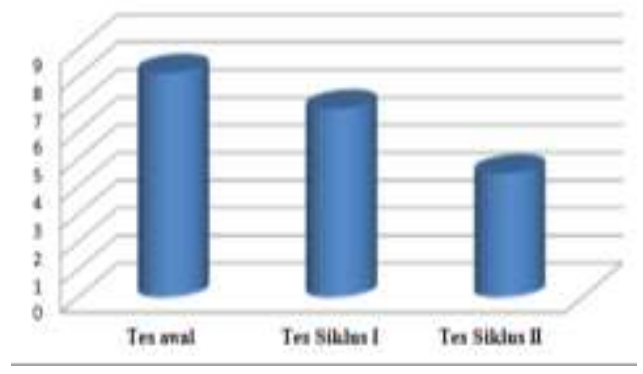

Gambar 2. Diagram Batang Nilai Simpangan Baku Hasil Belajar Fiqih Kelas II MIN 6 Langkat Bobrok
Diagram batang ini menunjukkan nilai simpangan baku pelajaran Fiqih siswa semangkin menurun, ini menunjukkan rentangannya semakin kecil, artinya model pembelajaran tersebut sangat sesuai dalam proses belajar mengajar dalam kelas.

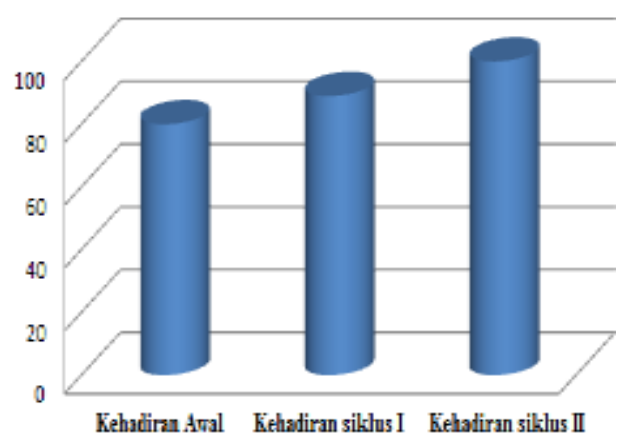

Gambar 3. Diagram Batang Nilai Rata-rata Kehadiran Kelas II MIN 6 Langkat Bobrok

Diagram batang ini menunjuk kan nilai kehadirannya semangkin meningkat, ini artinya model pembelajaran tersebut disenangi siswa, sehingga siswa aktif dalam mengikuti proses belajar mengajar di dalam kelas. 


\section{SIMPULAN}

Adapun kesimpulan yang dapat diambil pada penelitian ini :

Dengan Penerapan Model Pembela jaran Kooperatif Tipe Team Games Tournament (TGT) dapat meningkat- kan hasil belajar Fiqih siswa di kelas II Madrasah Ibtidaiyah Negeri 6 Langkat Bohorok, hal ini dapat dilihat dari hasil perhitungan korelasi antara nilai hasil belajar Fiqih siswa pada test awal (sebelum tindakan) terhadap nilai hasil belajar Fiqih siswa pada test akhir pertama (tindakan siklus I) sebesar 0,766 (kategori cukup signifikan) dengan nilai uji t sebesar 6,53, dan korelasi antara nilai hasil belajar Fiqih siswa pada test akhir pertama (tindakan siklus I) terhadap nilai hasil belajar Fiqih siswa pada test akhir kedua (tindakan siklus II) sebesar 0,95 (kategori sangat signifikan) dengan nilai uji t sebesar 16,578. Artinya terdapat hubungan yang sangat signifikan pada penelitian tindakan kelas.ini.

Dengan Penerapan Model Pembela- jaran Kooperatif Tipe Team Games Tournament (TGT) dapat meningkat- kan aktifitas belajar Fiqih siswa di kelas II Madrasah Ibtidaiyah Negeri 6 Langkat Bohorok, hal ini dapat dilihat dari hasil perhitungan sebelum dilaksanakan tindakan tingkat kehadiran rata-rata siswa $80 \%$, pada siklus I menjadi $89 \%$, pada siklus II menjadi 100\%, ini artinya siswa aktif dalam mengikuti proses belajar mengajar di dalam kelas.

\section{DAFTAR RUJUKAN}

Abdurrahman, M. 1999. Pendidikan Bagi Anak Yang Berkesulitan Belajar. Jakarta: Rineka Cipta.

Direktorat Jendral Pendidikan Islam. 2015. Buku Siswa, FIQIH, pendekatan Saintifik Kurikulum

13. Jakarta: Direktorat Jendral Pendidikan Islam, Depdiknas

Depdiknas. 2006. Pedoman

Pengembangan Model-Model

Pembelajaran Untuk SD/MI.

Jakarta: Direktorat PMPTK Depdiknas

Daryanto. 2001. Evaluasi

Pendidikan. Jakarta: Rineka Cipta

Ibrahim, M. 2000. Pembelajaran Cooperatif. Surabaya: Surabaya Press, UNS.

Ibrahim, R. \& Syaodih, S. 2003. Perencanaan Pengajaran. Jakarta: Depdiknas \& Rineka Cipta

Karsono. 2007. Pendidikan Matematika I. Jakarta: Pusat Penerbitan Universitas Terbuka Purwanto, N. 1990. Psikologi Pendidikan. Bandung: Remaja RoSMKakarya.

Suharjono. 2008. Penelitian Tindakan Kelas (PTK). Jakarta: Bumi Aksara. 